\title{
CONSTITUTIONAL LEGAL REGULATION OF ENVIRONMENTAL PROTECTION AND NATURE MANAGEMENT IN THE POST-SOVIET SPACE: ISSUES OF LEGAL TECHNIQUE
}

\author{
Aleksey Anisimov and Anatoliy Ryzhenkov
}

\author{
Department of Civil Law and Procedure \\ Kalmyk State University \\ Ulitsa Pushkina 11, 358000 Elista \\ Respublika Kalmykiya, Russian Federation \\ e-mail: anisimovap@mail.ru
}

\begin{abstract}
This paper deals with the issues of terminology and content of rules of the Constitution of the Russian Federation and the constitutions of several republics of the former USSR regulating relations in the field of nature management and environmental protection from the perspective of Hans Kelsen's normativism methodology, namely the Pure Theory of Law. The authors substantiate their conclusion that the constitutional rules in the countries of the post-Soviet space have a number of defects consisting of duplications or inadequate reflections of the legal reality. This leads to the suggestion for the need to conduct a search for options of enshrining rules on environmental protection and use of natural resources corresponding to realias of the 21st century in the future Constitution of Russia, which will allow creating an appropriate system of guarantees for everyone's rights to a favorable environment, the rights of citizens and legal entities to natural resources, as well as specifying their environmental and natural resources duties.
\end{abstract}

Key words: Constitution, natural objects, natural resources, natural wealth, jurisdictional issues, terminology

\section{INTRODUCTION}

Today one of the most urgent tasks of human civilization is to ensure the harmonious interaction of nature and society. A lack of this balance will inevitably cause the further destruction of ecological systems and deprive future generations of the possibility to live in a favorable environment. This task can only be settled on a worldwide scale by strengthening the role and significance of international cooperation whereby decisions adopted at the international level are to be implemented by means of national environmental legislation, the core of which are constitutions.

It is national Fundamental Laws that determine prospects for the development of environmental legislation, and the types and forms of state participation in legal regulations 
of social relations in the interaction of society and nature. The Constitution of the Russian Federation (hereinafter Constitution or Russian Constitution) is not an exception to this rule, being an act of supreme legal force and direct effect and serving as the legal basis for the development of all branches of Russian law. This is why it is not by accident that Article 9 of Chapter 1 of the Russian Constitution, establishing the fundamentals of the constitutional order, includes the rule that land and other natural resources are used and protected in the Russian Federation as the basis of life and activity of peoples living in the corresponding areas and can be in private, state, municipal and other forms of ownership.

Important clauses from the Constitution are Article 42 enshrining everyone's right to a favorable environment, reliable information on its condition and compensation for damage caused to health or property as a result of an environmental violation; Article 36 establishing the right of citizens and their associations to have private ownership of land, to possess, use and dispose of the land and other natural resources freely if this does not inflict damage to the environment and does not infringe on the rights and legal interests of other persons; Article 58 stipulating everyone's duty to preserve nature and the environment, treat natural wealth with due care, and, finally, Article 72 establishing joint jurisdictional issues of the Russian Federation and the subjects of the Russian Federation.

While we welcome consolidation in the Constitution of the legal fundamentals of environmental protection, we, nevertheless, are not supporters of the position on the inadmissibility of revision of the Constitution or the introduction of significant amendments thereto which has been gaining popularity in recent years (Boyko, 2004).

This position is based, first of all, on the analysis of the constitutional rules of Chapter 9 of the Russian Constitution establishing the order of introduction of constitutional amendments and revisions of the Constitution. Undoubtedly, the Constitution is a legal act of long-term effect, and stability is one of its main legal properties. However, the dynamics of social life and emergence of new economic and political realities should not, in our view, receive constitutional rules as a restriction Therefore, the introduction of amendments to the Constitution, and, subsequently, the preparation of its new text, will become a reality sooner or later.

Nevertheless, during preparation of the new text of the Constitution it is necessary to consider the drawbacks of the legal technique which we observe in the current Constitution. We should mention that its text was developed in great haste in terms of the severe political crisis that led to the tank shooting attack of the Russian Parliament building (Supreme Council) on 4 October 1993 (Kleshchenko, 2013).

Under these conditions there was no serious discussion about the draft Constitution either by the professional legal community or by the public, which caused the emergence of a number of defects in the legal technique. In legal science the latter is understood as "the system of professional legal rules and means used in drafting of legal acts and other legal activity in the fields of lawmaking, law interpretation, authoritative and 
non-authoritative implementation of law ensuring perfection of its form and content" (Davydova, 2010).

Further, on the basis of this definition we will study the content of rules of the Russian Constitution in the context of experience in the constitutional regulations of other countries of the post-Soviet space as well as the Russian branch (environmental and natural resources) legislation using Hans Kelsen's normativism methodology, which implies the elimination of all elements alien to juridical science (sociology, psychology, etc.) in the course of doctrinal studies (Kelsen, 1967).

This means that law must be studied as is but not as it must be; supporters of this concept are interested in real and possible but not "perfect" or "genuine" law. In this sense, the Pure Theory of Law is a radical realistic theory, i.e. a theory of legal positivism (Vorotilin et al., 1996). In addition, it should be noted that the Pure Theory of Law tends to divide the study of law from related disciplines certainly not because it does not notice or even deny this relation, but because it wishes to avoid the artificial connection that blurs the essence of the science of law, of dissimilar elements erasing the boundaries established by the nature of its subject itself. Undoubtedly, there are strong and weak points in any scientific concept and it is impossible to form some perfect concept explaining all the problems and contradictions in the development of law and containing ways to resolve them. The choice of Kelsen's scientific doctrine results from the goals of our research - to consider the dynamics of interaction of rules having different legal force, to try to understand the causes of imperfection of the legal technique, and to suggest solutions to these problems at the constitutional level. The methodology of normativism implies research in law as a regulatory form (and structure), the study of the rules of law that legitimize or delegitimize certain actions. Law in these terms is construed as a regulatory order of human conduct, that is, as a system of rules governing human conduct. As noted by Kelsen, "the notion of 'rule' implies that something must exist or be implemented and, especially, that people must act (conduct themselves) in a certain manner" (Kelsen, 1987).

From the perspective of the goals and objectives of this paper, Kelsen's ideas on the hierarchy of the rules of law are of most interest to us. Within this hierarchy, national law is a pyramid-shaped closed regulatory system in which every rule acquires bindingness due to its compliance with a rule of a higher level. At the top of the pyramid are constitutional rules as the highest "basic rule" reflected (or not) in the constitution and legislation; at the lowest level are individual rules created by courts or administrations while considering particular cases (Kraevsky, 2014). The basic rule is the foundation of validity of the regulatory order and corresponds directly with a certain real constitution of a state created on the basis of customs or by means of legislation, and indirectly with the legal order created in compliance with this constitution. Due to this correspondence with a certain constitution, the basic rule substantiates its validity as well as the validity of the relevant legal order (Kelsen, 1987). The importance of this methodology for our research consists in the fact that the fundamental constitutional rules must efficiently define the content and nature of "obligatoriness" with regard to all areas of social rela- 
tions, including use of natural resources and environmental protection. If this regulation is implemented ineffectively at the constitutional level and does not lead to the need for all bound subjects to perform actions covered by state coercion, these constitutional rules must be replaced or corrected. In these terms, it is especially important to consider them in context with branch legislation that must comply with the constitutional rules. Therefore, Kelsen's Pure Theory of Law precisely allows proving most convincingly the importance of the adequate regulation of all types of social (including environmental and natural resources) relations with constitutional rules that must be characterized both by internal consistency and successfully harmonized with branch rules of a lower level in the hierarchy of legal rules.

In the first section of the paper we will study the constitutional rules governing nature management, in the second part we will consider the constitutional legal regulation of environmental protection, and in the third we will summarize the identified gaps and conflicts of rules and suggest a number of solutions to remedy the current situation.

\section{CONSTITUTIONAL LEGAL REGULATION OF NATURE MANAGEMENT}

Three issues will be the main area of discussion within this section: adequacy of the terminology in use (in the context of the branch legislation); conflictness of consolidation in the Russian Constitution of the multiplicity of types and forms of ownership of natural resources; and content of "other forms of ownership" of resources that has not yet been specified.

\subsection{Issues of land terminology in the Russian Constitution}

The first aspect of the issue is that according to Article 36 of the Constitution of the Russian Federation, citizens of the Russian Federation and their associations are entitled to dispose of land and other natural resources freely if this does not cause damage to the environment or infringe on the rights and legal interests of other persons. This wording gives rise to a few questions. First, it is impossible to be the owner of "land" because one can possess, use and dispose of only a land plot - a part of the land surface which has officially set boundaries recorded in the state cadastre and which has undergone the procedure of state registration in a special register (Dzagoev, 2008). Similar considerations apply also to other natural resources. Secondly, environmental restrictions are established by this rule of the Constitution only for owners of land plots. Meanwhile, land plots can also belong to citizens and legal entities on the basis of lifetime ownership with hereditary succession, permanent (perpetual) use, easement, uncompensated use and lease.

Thirdly, the debatable aspect of the legal technique of Article 36 of the Constitution is that it uses the term "citizens" to describe the subjects of private ownership of land plots. The constitutionality of the rules of the Land Code of the Russian Federation regarding the possibility of foreign citizens and legal entities to acquire ownership of land plots 
raises a number of uncertainties. In fact, the Constitution enshrines most legal rights both for citizens of Russia and for stateless persons and foreign citizens. In such cases the term "everyone" is used in the Constitution. In Russia, everyone within its boundaries shall have the right to life (Article 20 of the Constitution), to a favorable environment (Article 42), to own property (Article 35), etc. This means that the subjects of these rights are all persons within the boundaries of Russia, regardless of sex, citizenship, nationality, official position, etc.

Exactly here the "national regime" manifests itself, i.e. we can observe the equalization of the rights of Russian citizens and foreign citizens (stateless persons). However, a number of legal rights are provided only to Russian citizens, for example, citizens of the Russian Federation have the right to participate in the management of state affairs both directly and through their representatives; citizens of the Russian Federation have the right to elect and be elected to state authorities and local government bodies; citizens of the Russian Federation have equal access to public service, etc. In compliance with Paragraph 1, Article 36 of the Russian Constitution, citizens and their associations shall have the right to have private ownership of land. If this right belonged to stateless persons and foreign citizens, in our view the term "everyone" would be suitable for this article of the Constitution.

The mentioned uncertainty of Article 36 of the Constitution became the subject of consideration of the Constitutional Court of the Russian Federation, which expressed its opinion on this issue. Appealing to the court and justifying its position, the applicant (Murmansk Regional Duma) stated that land is the basis of life and activity of the people living in the corresponding territory; in this case they include only the people of the Russian Federation; the law may not restrict or redistribute this basis, the right thereto in favor of persons not belonging to the people of the Russian Federation; from the Constitution it follows that only Russian citizens and their associations may be the subject of private ownership right to land; the provision of the ownership right to land to foreign citizens, persons without citizenship and foreign legal entities impairs the territorial basis of life and activity of the people of the Russian Federation, creates the possibility of alienation of land to a foreign state by means of transactions or territorial claims against the Russian Federation, and may lead to violation of the sovereignty of Russia.

In its judgment the Constitutional Court of the Russian Federation recognized the disputed articles of the Land Code of the Russian Federation as not being contrary to the Constitution. In particular, the Constitutional Court of the Russian Federation pointed out that the Constitution enshrines the "national regime" for foreign persons and stateless persons, i.e. in relation to rights and duties it equates them with Russian citizens. Implementing its constitutional duty, the federal legislator established the priority of Russian citizens regarding ownership of land, having introduced a number of restrictions for foreign citizens and legal entities, stateless persons in the exercising of the land use right (for example, in terms of the ban of acquisition of land plots in border territories). According to the Constitutional Court of the Russian Federation, this will be sufficient to ensure the sovereign rights of the Russian Federation to all of its natural 
wealth and resources, and also allows guaranteeing relatively equal conditions of competition with foreign capital for Russian citizens and legal entities. ${ }^{1}$

Fourthly, speaking about the legal technique of Article 36 of the Constitution, we should note that in addition to citizens, "associations" are mentioned as the subject of private ownership right to land. This defect is inherent also in other articles of the Russian Constitution. For example, according to Paragraph 2, Article 46 of the Constitution, decisions and actions (or inaction) of state authorities, local self-government bodies, public associations and officials may be appealed against in a court of law. Meanwhile, the civil legislation stipulates many varieties of commercial and non-commercial legal entities, and public associations are just one of the varieties of non-commercial legal entities. Therefore, use of the term "association" here is inaccurate because from the context of Article 36 of the Constitution it follows that it refers to legal entities.

In this regard, we suggest the following amendment to Article 36 of the Constitution: "1. Everyone shall be entitled to have private ownership of land plots.

2. The possession, use and disposal of land plots and other individualized natural resources shall be freely performed by their proprietors provided this does not cause damage to the environment or infringe upon the rights and legal interests of other persons." Along with Article 36 of the Constitution, defects of the legal technique can also be observed in relation to other articles of the Fundamental Law. For example, according to Paragraph 3, Article 35 of the Constitution, "compulsory expropriation of property for state needs may be performed only subject to prior and fair compensation". Consideration of this rule in the context of the land legislation gives rise to a number of questions. The matter is that Article 49 of the Land Code of the Russian Federation stipulates withdrawal of land plots for state or municipal needs. Consequently, compliance of the procedure for withdrawal of a plot for municipal needs not stipulated by Article 35 of the Constitution with the Land Code of the Russian Federation is still an open question. Moreover, withdrawal of property for state needs is subject to compensation. But is the withdrawal of property (for example, a land plot) for municipal needs subject to similar compensation? Land and civil legislation give an affirmative answer to this question. However, this conclusion does not follow from the constitutional rules. Regarding this question, there is the legal position of the Constitutional Court of the Russian Federation (2008) which explained that the people exercise their power through state authorities and local government bodies. The provision of local government bodies with authorities for compulsory expropriation of land plots, in exceptional cases related to placement of objects of municipal significance, in case of lack of other options of probable placement of such objects, is caused by the need to settle publicly important issues of local significance, and the procedure for its implementation is associated with the same

1 Judgment of the Constitutional Court of the Russian Federation of 23 April 2004 No. 8-П in the case concerning the review of the constitutionality of the Land Code of the Russian Federation in connection with the request of Murmansk Regional Duma (Constitutional Court of the Russian Federation, 2004) 
conditions that are stipulated for cases of expropriation of property for state needs. Consequently, rules of laws enshrining withdrawal of land plots for municipal needs are not contrary to the Constitution. Meanwhile, this interpretation, actually equating state authorities and local government bodies, can hardly be recognized as convincing. The reason for the emergence of such requests and such explanations of the Constitutional Court of the Russian Federation lies precisely in the area of the legal technique.

\subsection{Reasonability of consolidation in the Constitution of Russia of the diversity of types and forms of ownership of natural resources}

In the context of the second issue we should note that Article 9 of the Constitution of the Russian Federation mentions diversity of types and forms of ownership of natural resources. Traditionally, the following six types of natural resources are distinguished: land, water, mountains, forests, fauna, air. There are corresponding federal laws adopted for each type of natural resource and governing their ownership issues. But does real diversity of types and forms of ownership of all natural resources follow from these laws?

1. Land. Chapter III of the Land Code of the Russian Federation (Articles 15-19) establishes that land plots may be in private, state (the Russian Federation and its subjects) and municipal ownership, which fully complies with the provisions of the Constitution of the Russian Federation.

2. Forests. Forests as a natural object and a natural resource can grow on lands of the forest fund and lands of other categories. By virtue of Article 8 of the Land Code of the Russian Federation, forest sites included in lands of the forest fund are in federal ownership. In this respect we should note that forests can also grow on lands of other categories (for example, within the boundaries of national parks or other specially protected natural areas), but in these cases they fall under the legal regime of other categories of lands. For example, a forest can grow within the boundaries of a natural park owned by a subject of the Russian Federation, and in this case it will belong to the subject of the Russian Federation. However, this and similar exceptions to the rules only confirm the prevalence of federal ownership of forests.

3. Water. According to Article 8 of the Water Code of the Russian Federation, water objects are in federal ownership, except for ponds and flood bypass conduits, which may be in private and municipal ownership as well as in ownership of subjects of the Russian Federation.

4. Subsoil. By virtue of Article 1.2 of the Law of the Russian Federation "On Subsoil", subsoil is in state ownership, i.e. in ownership of the Russian Federation and its subjects. Municipal and private ownership of subsoil and mineral resources contained in it are not stipulated by the law.

5. Fauna. According to Article 4 of the Federal Law "On Fauna", fauna within the boundaries of Russia is in state ownership, i.e. in ownership of the Russian Federation and its subjects.

6. Atmospheric air. Issues of ownership of atmospheric air in Russia (in contrast to China) have not been settled, although the state performs functions of disposing of it, for example, establishing emission limits. 
Table 1. Ownership of natural resources

\begin{tabular}{|c|c|c|c|c|c|}
\hline No. & Natural resources & $\begin{array}{c}\text { Ownership of } \\
\text { the Russian } \\
\text { Federation }\end{array}$ & $\begin{array}{c}\text { Ownership } \\
\text { of subjects of } \\
\text { the Russian } \\
\text { Federation }\end{array}$ & $\begin{array}{c}\text { Municipal } \\
\text { ownership }\end{array}$ & $\begin{array}{c}\text { Private } \\
\text { ownership }\end{array}$ \\
\hline 1 & Land & Yes & Yes & Yes & Yes \\
\hline 2 & Forests & Yes & No & No & No \\
\hline 3 & Water & Yes & Yes & Yes & Yes \\
\hline 4 & Subsoil & Yes & Yes & No & No \\
\hline 5 & Fauna & Yes & Yes & No & No \\
\hline 6 & Atmospheric air & No & No & No & No \\
\hline
\end{tabular}

The overview above shows that only the land legislation fully complies with the rule of the Russian Constitution under consideration (Article 9); we can speak about partial compliance of the water legislation (in terms of ponds and flood bypass conduits - of an extremely small part of water objects) and forest legislation (in case of forests located on lands not included in the category of lands of the forest fund).

With regard to the other three types of natural resources (subsoil, fauna and atmospheric air), we can speak about the complete contradiction between the legislation and Article 9 of the Constitution stipulating diversity of types and forms of ownership of all natural resources. Within the spirit of Kelsen's theory, we can say that this constitutional rule is not the basis of an effective compulsory order because the branch legislation on natural resources is contrary to the Constitution with perfect impunity. However, the essence of our suggestions is not to bring these laws into compliance with the Constitution. On the contrary, what we suggest, in case of preparation of a new edition of the Russian Constitution, is the exclusion of the possibility for all types of natural resources to be in all forms of ownership, that is, introduction of amendments (as Kelsen would say) to the very basic rule reflected in the Constitution. In our view, Part 2 of Article 9 of the Constitution must be edited as follows: "2. Land plots and water objects may be in private, state and municipal ownership. Forests and subsoil may be in state and municipal ownership. Fauna and atmospheric air shall be in federal ownership". Adoption of this edition of Part 2 of Article 9 of the Constitution would allow for creating a background for development at the lower levels of the legislation hierarchy of the ownership rights of subjects of the Russian Federation and municipalities to water, ${ }^{2}$

2 In our view, it is reasonable to transfer water objects completely located within the boundaries of subjects of the Russian Federation into their ownership; in a similar way, municipal ownership must include not only ponds and flood bypass conduits but also other local water objects completely located within their boundaries. 
forests and subsoil; ${ }^{3}$ the exercise of any ownership right to fauna and atmospheric air is problematic (and this will not change after any period of time), which is why a federal ownership right is optimal. Extension of the private ownership right to individualized natural resources requires a separate discussion. We do not see insurmountable obstacles to private ownership of certain forest sites, subsoil or a wider range of water objects but such decisions can be adopted only subject to an effective system of state administration and control, which is only just emerging in Russia.

In this respect, the experience of other republics of the former USSR is interesting. For example, no country has an exhaustive list of natural resources referring to a particular form of ownership. Thus, the priority of state ownership of subsoil, water and forests is enshrined in Article 13 of the Constitution of the Republic of Belarus; this list is broader in the Constitution of the Republic of Lithuania, and includes parks, roads and airspace (Article 47); the Constitution of the Republic of Kazakhstan (Article 6.13) mentions flora and fauna, which is not observed in other constitutions. As such, the Constitution of the Republic of Armenia (Article 28) clearly emphasizes that foreign citizens and stateless persons do not have ownership right to land, which is not observed in the constitutions of other countries of the post-Soviet space.

This list can be continued, however, let us draw attention to the following circumstance. There are three models of constitutional consolidation of the ownership right to natural resources in the constitutions of the former republics of the USSR. In some this issue is settled unambiguously and in sufficient detail (Russia, Kazakhstan, Lithuania, etc.). In others the legislator did not regulate the types and forms of ownership of natural resources (Armenia). In others still (Ukraine) the legislator perceives the concept of "property of people" and withdraws from the classical listing of types and forms of ownership. In the latter case we are speaking about Article 13 of the Constitution of the Republic of Ukraine, according to which land, its subsoil, atmospheric air, water and other natural resources located within the territory of Ukraine, natural resources of its continental shelf, the exclusive (marine) economic zone are objects of the ownership right of the Ukrainian people.

Analyzing the concept of property of the people, its political, ideological and other aspects and peculiarities would go beyond the normativism methodology of scientific studies and therefore such will not be conducted. However, taking into account the emergence of the relevant constitutional rules in the constitutions of the republics of the former USSR and the probability of the spreading of this trend to other countries, it is still necessary to say a few words about this concept. The legal argumentation of supporters of this concept on its own looks very attractive. They assert that the objective impossibility to exercise the rights of ownership (even a public one) in relation to

3 We believe that the transfer of city forests and certain areas of subsoil (not intended to ensure the country's security) into municipal ownership will facilitate development of the economic basis of the local self-government, and, correspondingly, enhancement of the quality of municipal administration and standard of living. 
most natural resources requires constitutional consolidation of the concept "property of the people" covering all types of natural resources. The arguments of supporters of this concept are that no ownership of atmospheric air is possible in principle; for the same reason (due to constant movement) private or public ownership of water resources is impossible; owners of fauna cannot exercise the right of possession, since they do not perform control (and do not know about the number) of their property - these objects being fauna. Finally, public owners of subsoil do not know how many mineral resources are located in the subsoil, while, according to the rules of civil law, one cannot be the owner of unknown objects (Sotnikova, 2009).

Representatives of this scientific school believe that people may be the subject of constitutional relations, and it is the people who delegate the rights of ownership of natural resources to the state. Correspondingly, the legal regime of "property" as people's ownership must be properly reflected in the Constitution. In addition, the Constitution and other laws must establish a precise list of objects (assets) that are the property of the people, in order to exclude the possibility for someone to illegally dispose of this property and use it in their own interests. As noted by E. P. Petukhova, the constitutional legal regime of national property is expressed in the fact that this is the procedure for regulation of social relations enshrined by the Constitution which is formed regarding the most valuable and unique natural objects, aimed at their conservation and protection from irrational and unjustified actions of man and the state in order to satisfy the interests of the entire multinational people and preserve unique natural resources for future generations (Petukhova, 2015).

Based on the above, supporters of this concept draw the conclusion about the necessity to supplement the constitutional and natural resources legislation with a new legal structure "national (people's) property", which must include most natural resources. Correspondingly, either the category "types and forms of ownership" of natural resources must be rejected at all or "other forms" of ownership must be equated with national property which must cover relations of "possession" for all natural resources (Melikhov, 2007).

Despite the attractiveness of this concept, we should note that introduction of amendments to the Russian Constitution and enshrining therein of rules on national property can hardly enhance the quality of legal regulation of natural resources relations. The structure "property of the people" has been enshrined in a number of constitutions of the USSR, however, this did not have any positive effect. In the case of Ukraine, we can see that enshrining the ownership right of the people in its Constitution did not lead to a transformation of views about ownership of land and other natural resources at the lower hierarchical levels of the natural resources legislation.

Nevertheless, if this concept is turned not into a declaration but a legal rule in effect, there are many insoluble issues associated with the administration of nature management (problems with the quality of which are increasingly often mentioned in scientific literature) (Epshtein, 2006) or the procedure for provision of some or other natural resources for use or their lease. In this respect, the position of "taking into account the 
significance of natural resources, public interests of the public owner, the category of people's property should be considered as a collective feature of the special constitutional legal regime of natural resources" is more convincing (Soldatenkov, 2009).

\subsection{Constitutional regulation of "other forms" of ownership}

As already noted above, Article 9 of the Russian Constitution mentions (but does not clarify) "other forms of ownership". At the legislative level we can find a sufficient number of various "nonstandard" forms of ownership potentially falling under the constitutional "other" forms of ownership. For example, the laws of the early 1990s also mentioned (except private, state and municipal) "collective ownership", "ownership of public associations", "ownership of legal entities", etc. Different scholars have tried to interpret the established uncertainty in their own ways. For example, some authors assumed that in Russia church ownership was on the rise, and, in addition, there was collective ownership - of trade unions, cooperatives, and social organizations (Velento, 2003). One of the supporters of this concept (Demyanenko, 2004) in his works substantiated in detail the need to understand cooperative ownership, which is not private, state or municipal, as "other forms of ownership". Other authors proved that "other forms of ownership stipulated by the Constitution is collective (corporate) and personal ownership" (Tarkhov et al., 2006). Still others distinguished ownership of state corporations as "other" ownership (Kleandrov, 2008). And there are also those who wrote that new forms of ownership would emerge in the future, because economy was higher than law, but already then they could speak about ownership of Cossack societies, communities of indigenous peoples, etc. (Chubukov, 2003).

Despite all the unquestioned advantages of the suggestions above, we should note that trade unions, cooperatives, Cossack associations and religious organizations are nothing more than particular varieties of legal entities the specifics of which are not sufficient for such a global conclusion about the emergence of new types and forms of ownership. Within the framework of this approach it will be much more reasonable to consider joint shared and joint unshared ownership (Samusenko, 2015), or ownership of foreign states of land plots occupied by embassies (Selifonova, 2012) as "other forms of ownership". ${ }^{4}$

Summarizing the above, we should point out that appropriate legal regulation of ownership relations of natural resources is one of the key issues in the area of environmental economics and politics as a scientific discipline. A considerable part of environmental economics is connected with determining where and under which circumstances the ownership right to natural resources or turnover of environmental goods and services may be violated as well as what is the best way to avoid it. This is exactly why a clear delineation (including by means of constitutional rules) of private and public owner-

\footnotetext{
4 It is worth noting that constitutions of all other republics of the former USSR (except Russia) do not provide for "other forms of ownership", limiting themselves to generally accepted types and forms of ownership, mainly private and state.
} 
ship of natural resources allows enhancing management approaches to their use and protection, including at various territorial levels (the Russian Federation, subjects of the Russian Federation, local government bodies).

\section{CONSTITUTIONAL LEGAL REGULATION OF ENVIRONMENTAL RELATIONS IN THE RUSSIAN FEDERATION AND REPUBLICS OF THE FORMER USSR}

As in the case of natural resources, the constitutional regulation of environmental protection includes a range of problems: content-related; common drawbacks of terminology; problems of delineation of jurisdictional issues; problems of terminology in the field of environmental duties.

\subsection{Content of constitutional environmental rights}

According to Article 42 of the Russian Constitution, everyone shall be entitled to a favorable environment, reliable information on its condition and compensation for damage caused as a result of environmental violations. We should support the conclusion drawn in recent research studies on constitutional law about the subjectivity of the legislator's approach to include in the Fundamental Law some legal rights objectively available and stipulated by international legal acts (to environmental information, compensation for damage), and the complete disregard of other ones (to association or participation in adoption of decisions affecting environmental rights and duties of citizens). In terms of discussion we would suggest a conclusion about the reasonability of enshrining in the Fundamental Law of only the fundamental environmental right - to a favorable environment, without specifying other environmental rights being just the means of its exercise (Fokin, 2006). This approach is implemented in many of the constitutions of foreign countries. For example, according to Article 35 of the Constitution of the Republic of Korea (South Korea), citizens shall have the right to a healthy and favorable environment. The state and the citizens undertake all measures to protect the environment (Vystorobets, 2012).

\subsection{Common drawbacks of environmental terminology in the Constitution}

There are three types of terminological problems that can be distinguished.

1. In compliance with Item "e", Part 1, Article 72 of the Russian Constitution, "specially protected natural areas" (SPNAs) are a certain joint jurisdictional issue of the Russian Federation and subject of the Russian Federation. The importance of special protection of unique and valuable natural complexes is beyond anyone's doubt. However, this gives rise to two questions. First, the rules establishing the legal regime of specially protected natural areas form an institution of a special part of environmental law (Erofeev, 1996). Along with the importance and necessity of 
this legal institution, other institutions of environmental law are no less important, for example, the institution of environmental supervision or legal liability for environmental violations. Consequently, it is obvious that there is a lack of a single basis for singling out certain institutions of environmental law at the constitutional level. Second, the environmental legislation that was in effect before adoption of the Constitution (in the same way as the one in effect now) provided for two varieties of territories with a special environmental legal status: specially protected natural areas and environmental emergency zones (ecological disaster zones). Both of the mentioned varieties implied provision of a special environmental legal status to a particular territory, in one case "positive", aimed at its withdrawal from economic turnover in order to preserve the unique natural complexes and landscapes in their original form (Chernushenko, 1999), and in another case "negative", aimed at the adoption of a set of urgent measures for rehabilitation of degraded natural complexes and restoration of the favorable quality of the environment (Kasprova, 2014). As a result, one variety of the "territorial" aspect of environmental protection is included in the Constitution, and the other one is not. In addition, other types of territories with a special legal status are mentioned in scientific literature, and they are also absent in the Constitution (Mayasov, 2013).

Here we should mention the Constitution of the Republic of Ukraine, which settles this issue in an appropriate way. For example, according to Article 85, authorities of the Verkhovna Rada of Ukraine include declaring certain localities as environmental emergency zones; the legal regime of environmental emergency zones is determined exclusively by laws of Ukraine (Article 92); the President has the right to declare certain localities of Ukraine as environmental emergency zones - with the subsequent approval of these decisions by the Verkhovna Rada of Ukraine, etc. The adoption of this decision by the legislator of Ukraine may be explained by the consequences of the accident at the Chernobyl Nuclear Power Plant in April 1986 that have not yet been eliminated. They had a strong impact on public sentiment and have been reflected in the text of the Constitution of Ukraine. In Russia, a lack of similar rules in the Constitution does not allow granting a special status to territories affected by global climate change, natural and manmade disasters. Meanwhile, the rupture of the pipeline at the Lovinskoe field in 2003 (not far from Khanty-Mansi region), which led to an outflow of more than 10 thousand tons of oil, can be attributed to major ecological (manmade) disasters in Russia of recent years. The Mulymia River was covered with oil film 100 kilometers long, and there was mass extinction of flora and fauna. The accident at the Sayano-Shushenskaya Hydroelectric Power Plant on 17 August 2009 is an equally well-known example. It caused pollution of the Yenisei River and the deaths of 75 people.

Third, are the issues of creation and the functioning of SPNAs not governed by the environmental legislation mentioned in the same article?

2. A question that is no less complex is the fact that Item "e", Part 1, Article 72 of the Constitution of Russia establishes environmental protection and ensuring environ- 
mental security as a certain joint jurisdictional issue. In order to clarify the relationship of the said concepts, let us refer to Article 1 of the Federal Law "On Protection of the Environment" of 10 January 2002 No. 7-FZ.

According to this law, environmental protection is an "activity of state authorities of the Russian Federation, state authorities of subjects of the Russian Federation", local self-government bodies, public and other non-commercial associations, legal entities and individuals aimed at preservation and restoration of the natural environment, rational use and reproduction of natural resources, prevention of negative impact of economic and other activity on the environment and elimination of its consequences".

Environmental security is "the state of protecting the natural environment and vital interests of people from possible negative impact of economic and other activity, natural and manmade emergencies and their consequences". Comparing the above two categories, some authors believe that "environmental security is a more comprehensive concept than environmental protection, since it includes not only ensuring the favorable state of the environment but also ensuring the environmental interests and needs of man, society and state" (Velieva, 2011), and "among the areas of activity of authorized bodies and persons in this field sanitary and epidemiological, hygienic, technological and other measures aimed at ensuring environmental security can be pointed out" (Velieva, 2011). Is it possible to agree with this approach? This appears to have a polemical nature.

We ask ourselves the question: what is the nature protection activity aimed at, what is its purpose? It appears that the purpose is to ensure environmental security. This conclusion is quite common in scientific literature (Zhelezinsky, 2011). M.M. Brinchuk is one of the first who raised the issue of the relation of the said concepts in his works. Analyzing the definitions existing in scientific literature, Brinchuk notes that some authors perceive "environmental security" as an integral part of environmental protection while other scholars equate them, and still others include not only environmental protection but also rational nature management and improvement of the quality of the environment in "environmental security"; fourth ones write that ensuring environmental security is the activity carried out along with environmental protection. Brinchuk reasonably believes that ensuring environmental security is not an independent area of practical activity carried out along with environmental protection. Environmental security is the main principle of environmental protection meaning that any practical activity associated with harmful impact on nature, as well as legal and other environmental measures provided for in the law, should be assessed from the viewpoint of ensuring environmental security (Brinchuk, 1998).

Therefore, it is more logical to understand ensuring environmental security as the purpose of environmental protection. However, the reference to the activity and its purpose in the Fundamental Law it is hardly reasonable, especially taking into ac- 
count the fact that this is not done with regards to other branches of the legislation. Moreover, in addition to environmental security (which is not only the purpose of environmental protection but also governed by the rules of environmental legislation), other types of security (food (Faizullin, 2010), nuclear (Kozhevnikov, 2015) energy (Gafurov, 2010) etc.) are mentioned in research papers and the branch legislation, and the legislator did not include these in the Russian Constitution.

3. In conclusion of this section we note that in Article 72 of the Constitution it is necessary to enshrine the concept "environmental legislation" instead of the available term "legislation on environmental protection" (Chertova, 2007), in the manner similar to that of land, water, forest and other legislation.

\subsection{Delineation of jurisdictional issues relating to environmental protection between the Russian Federation and its subjects}

In compliance with Part 1, Article 72 of the Russian Constitution, joint jurisdiction of the Russian Federation and subjects of the Russian Federation includes (Item "c") issues of the possession, use and disposal of the land, subsoil, water and other natural resources. Meanwhile, in compliance with Item "e" joint jurisdiction includes issues of management of natural resources, and according to Item "j" joint jurisdiction includes land, water, forest and subsoil legislation. Several questions emerge here.

First, does the legislation mentioned in Item " $j$ " regulate the issues of possession, use and disposal of corresponding natural resources, and if so, what is the point of the duplication of the same types of activity twice in one article? Second, nature management is usually understood as a set of all forms of exploitation of the natural resources potential and measures for its conservation (Reimers, 1990). In addition, these forms will inevitably include water management, forest management, etc. But will the said forms of impact not be regulated by the land, water, forest and other legislation stipulated by Item " $j$ ”, Part 1, Article 72 of the Constitution? It seems that another duplication of the provisions of Item " $\mathrm{j}$ " is obvious.

Third, the lack of references to the fauna legislation regulating issues of use and protection of fauna objects in Item " $j$ " gives rise to several questions at once. On the one hand, we can assume that the legislator did not single out relations of use and protection of fauna objects as independent ones, suggesting their regulation by the rules of environmental law. However, in this case it is not clear why the relations of use and protection of some natural resources receive (in contrast to other ones) more precise legal regulations, taking into account that each natural resource is essential for mankind and equally important in any other aspect. Moreover, inclusion by the Constitution of some natural resource relations in environmental ones and leaving aside other natural resource relations is contrary to the current standards of the legal technique. Therefore, it appears that the land, water, mountain, forest and other natural resource branches of law are totally equal to each other and other branches and differ only in the degree of their regulative development, which is due to particular historical conditions and rea- 
sons, as has been repeatedly noted in legal literature (Kolbasov, 1976).

On the other hand, in our view, we can assume that the legislator refers the fauna legislation to issues of exclusive jurisdiction of subjects of the Russian Federation (Article 73 of the Constitution). In this case adoption, for example, of the law "On Hunting" by a subject of the Russian Federation would allow regulating the procedure for use of fauna objects in a different way than stipulated by the federal regulatory legal acts. In addition, the law of the subject of the Russian Federation will have a greater legal force (Part 6, Article 76 of the Constitution). However, the current legal positions of the Constitutional Court of the Russian Federation exclude the possibility of such interpretation of said constitutional rule.

In our view, one of the attempts to settle the mentioned polemical questions could be the adoption at the federal level of a certain law establishing issues of exclusive jurisdiction of subjects of the Russian Federation.

Fourth, the location of the air legislation requires a separate discussion. It is not mentioned in the Constitution either, although atmospheric air is the same natural resource as the others.

\subsection{Constitutional regulation of environmental duties}

According to Article 58 of the Russian Constitution, everyone shall be obliged to preserve nature and the environment, treat natural wealth with due care. This wording invokes two questions: which subjects fall under the term "everyone" and what should be understood as natural wealth. Answering the first question, we note that the Constitution uses two addressees of legal rights and legal duties - "citizens" and "everyone". In the latter case, we mean both citizens of Russia and foreign citizens or stateless persons covered by the constitutional rules. But can we think that the environmental duties in Article 58 of the Constitution apply not only to citizens (including foreign ones) but also to legal entities? (Kuzmin, 2007). Based on the branch environmental legislation, the answer must be positive. The relevant interpretation of Article 58 is very common in scientific literature (Proshina, 2014). Some authors include not only citizens and legal entities but also the state (Basik, 2003) in subjects covered by the term "everyone" in Article 58, however, all the positions set forth do not follow directly from the Constitution.

Another aspect of environmental duties is in the interpretation of the category "natural wealth", which should be protected by everyone. The problem is that at the moment the content of most terms used in Russian environmental legislation is clarified in Article 1 of the Federal Law "On Protection of the Environment" of 10 January 2002 (revised on 19 July 2018); however, the term "natural wealth" is not mentioned therein. Correspondingly, it is impossible to establish what place the category "natural wealth" has in the system of environmental terminology, and how this term relates to adjacent legal categories, including "natural objects" and "natural resources". Nevertheless, the term "natural wealth" mentioned in the Constitution is mentioned twice in the Federal Law "On Protection of the Environment" of 10 January 2002. The first is in the preamble of the law where it is stated that "everyone shall be obliged to protect nature and the 
environment, treat natural wealth with due care". The second is in Article 11 where the legislator passes from declarations to establishment of direct legal duties, providing for (Item 3) the duty of citizens "to treat nature and natural wealth with due care". Enshrining of such duties requires a study of the mechanism of their implementation, however, for this purpose it is necessary to determine what exactly is understood by the legislator as "natural wealth", and what set of bans and restrictions in this regard must be imposed on certain subjects of environmental legal relations. In order to answer this question, it is necessary to find out the regulatory origin of this term.

The term "natural wealth" was widely used in the constitutions and laws of the Soviet Union and the RSFSR. For example, according to Article 18 of the Constitution (Fundamental Law) of the USSR of 7 October 1977, in the interests of present and future generations in the USSR necessary measures shall be adopted, including those to ensure reproduction of natural wealth enhancement of the environment that surrounds man; Article 67 of the Constitution of the USSR stipulated the duty of citizens of the USSR to take care of nature and protect its wealth.

The term "natural wealth" was mentioned also in Article 1 of the Law of the RSFSR "On Protection of Nature in the RSFSR" of 27 October 1960. According to this article, state protection and regulation of use in the territory of the RSFSR included all natural wealth involved both in the economic turnover and the unexploited: land; subsoil; water (surface, underground waters and soil moisture); forests and other natural vegetation, green plantations in settlements; typical landscapes, rare and remarkable natural objects; resort areas, forest protection belts and suburban green areas; fauna (useful wild fauna); atmospheric air. The provisions of Article 20 of this law are very important in understanding the legislator's logic. According to these provisions, institutions, enterprises and organizations which are provided with land plots and other natural wealth shall be obliged to ensure the protection, rational exploitation and reproduction of natural resources. Hence it follows that in the last century the legislator first tried to include not only natural resources that are subject to economic exploitation in the category of "natural wealth" but also natural objects withdrawn from the economic turnover, and second, referring to certain duties of nature users, the legislator tried to equate the categories "natural wealth" and "natural resources".

This legislative trend was reflected in detail also in Russian environmental legal science. For example, N. B. Mukhitdinov writes that "natural wealth of the country, subsoil, forests, water and land, being the exclusive property of the state, may be provided only for use" (Mukhitdinov, 2010). N. D. Kazantsev (1965) notes that all natural wealth in the USSR is the single state fund of natural resources which includes, along with the land, forest and water funds, and also the geological fund (the fund of mineral resources). These terms are often also used as synonyms in modern studies dedicated to corruption in the field of use of natural wealth (natural resources) (Khalilova et al., 2016).

Other authors equate the legal categories "natural wealth" and "natural objects". As noted by A. A. Ivanov, the term "natural wealth" can be applied "to every object of nature associated with reasonable and volitional activity of man. Nature itself is wealth. 
However, in the context of the relevant article of the Russian Constitution, wealth of subsoil, flora, fauna and other natural objects that people use to satisfy their needs is meant" (Ivanov, 2016).

In turn, Brinchuk states that the legal regime of natural objects is "the set of legal methods and measures to regulate social relations with respect to land, subsoil, water, other natural wealth as objects of ownership, use and protection" (Brinchuk, 2011).

A third group of authors believes that the Russian Constitution points out "nature, the environment and natural wealth" as independent objects subject to preservation and conservation (Takhvatulina, 2006). E. P. Petukhova notes that "natural wealth, natural resources, natural objects, natural territories are used as the basis for life of the population of the country as well as for everyday activity, economic activity, entrepreneurial activity, public activity of the population of the country". In addition, "use, consumption, exploitation of the natural resource, natural object, natural territory, natural wealth and mineral resources must comply with the goals of sustainable development of society..." (Petukhova, 2015). The latter position means that mineral resources are an independent legal category that is not included in either natural resources or natural objects or natural wealth, which is difficult to agree with. It appears that mineral resources are a particular variety of natural resources. ${ }^{5}$ Therefore, within the framework of the third concept, either the legal category "natural wealth" coexists with "nature" and the "environment", or "natural wealth" is recognized as being equivalent and the same independent category as "natural objects" or "natural resources". In general, all the above positions are of a polemical nature, since the environmental legislation does not imply confusion of terminology, and therefore natural resources and natural objects have very clear and particular content. The law neither provides for the possibility of their equation with each other nor with the constitutional category "natural wealth", which cannot absorb or replace them (even if we consider it as really functioning).

As an argument in favor of saving the term "natural wealth" in the Russian Constitution, we can cite the example of a number of other countries in whose constitutions this term is actually used. For instance, according to Article 11 of the Constitution of the Kingdom of Bahrain, "natural wealth and resources are State property"; Article 15 of the Constitution of the Republic of Bulgaria states that "the Republic of Bulgaria shall ensure protection and reproduction of the environment, maintenance of living nature and its diversity and reasonable use of the country's natural wealth and resources"; Article 58 of the Constitution of the Democratic Republic of the Congo states "All Congolese have the right to enjoy national wealth"; Article 52 of the Constitution of the Republic of Croatia mentions "sea, seashore and islands, water, air space, mineral resources and other natural wealth..."; according to Article 7 of the Constitution of the Czech Republic, "the state shall concern itself with the prudent use of its natural resources and the protection of its natural wealth";

5 The constitutions of several countries (Bangladesh, Bhutan, Cambodia, etc.) actually mention mineral resources; however, there are no reasons for direct borrowing of their experience. 
according to Article 5 of the Constitution of the Republic of Estonia, "the natural wealth and resources of Estonia are national riches which must be used economically". This list of rules of constitutions of foreign countries can be continued.

Meanwhile, foreign experience is acceptable for borrowing only when it fits into the national legal system and allows for solving problems existing in the state without leading to side effects. In this respect, for example, it is impossible to implement the experience of work of English courts in Russia, since Russia belongs to the system of civil law, and the United Kingdom to the system of common law. In a similar way, and in terms of the given examples, this experience cannot be a role to emulate, since Russia has its own rather unique legal system based on centuries-old legal traditions. For example, in contrast to the Kingdom of Bahrain, in Russia neither private nor public ownership of natural wealth and natural resources is possible. A land plot (water object) can be in private (state) ownership, but not land or water in general. In contrast to Estonia or Croatia, mineral resources cannot be a certain type of natural wealth or resources within the framework of the Russian legislation all natural resources are equivalent, and the Constitution of the Russian Federation does not give priority to mineral resources. Therefore, at the moment "natural wealth" is a term of the Russian constitutional law, the content of which has not been clarified in the branch (environmental) legislation. Due to its doctrinal interpretation we can draw the conclusion that this term just duplicates the concept "natural resources" including all components of the natural environment (lands, water, forests, etc.) which can be used in the economic activity of man. Since the term "natural wealth" does not carry a semantic load, it is necessary to exclude the reference to the need "to treat natural wealth with due care" from Article 58 of the Constitution of Russia, having amended it to read as follows: "Everyone shall be obliged to protect the natural environment". The latter sentence may be substantiated by the fact that the current edition of Article 58 of the Constitution mentions the need to "protect nature and the environment", which makes no sense, since the environmental legislation clearly distinguishes "the environment" and "the natural environment".

If the first one includes "a set of components of the natural environment, natural and natural-anthropogenic objects as well as anthropogenic objects", the second one does not include "anthropogenic objects".

Therefore, it makes no sense to mention the need to protect both nature and the environment at the same time, because the environment is a broader concept including anthropogenic objects that are not part of nature. That is why the natural environment will be a more suitable object of legal protection. Correspondingly, it is necessary to delete the rules that oblige citizens to take care of natural wealth from the Law of the Russian Federation "On Protection of the Environment", because this duty is implemented through a number of certain rules dedicated to protection of natural resources and natural objects. ${ }^{6}$

6 In this respect, the experience of other republics of the former USSR is interesting as it can both coincide and not coincide with the Russian one. For example, by virtue of Article 55 of the Constitution of the Republic of Belarus, "protection of the natural environment is the duty of everyone"; according to Article 


\section{WAYS AND METHODS TO ELIMINATE DRAWBACKS OF STATUTORY REGULATION OF ENVIRONMENTAL AND NATURAL RESOURCES RELATIONS IN THE CONSTITUTION}

In Russian legal literature there are many critical remarks on the Russian Constitution and suggestions on how to correct particular defects of constitutional rules on nature management and environmental protection. For example, M. A. Vakula suggests supplementing the Constitution with a number of principles of environmental law, including the principle of payment for nature management and compensation for damage to the environment, independence of control in the field of environmental protection among others (listed in Article 3 of the Federal Law "On Protection of the Environment"), which will allow "using the mechanisms of constitutional justice to optimize constitutional legal regulation in the field of environmental protection and rational nature management and reduce the possibility of excessive centralization of environmental law at the federal level" (Vakula, 2011).

O. T. Serikov makes similar suggestions on supplementing the Constitution of the Republic of Kazakhstan with principles of sustainable development (Serikov, 2010). However, despite the attractiveness of this, it should be rejected, since the volume of any constitution objectively has a limited nature. Other authors consider it necessary to include in the Russian Constitution "the goal of the state of an environmental nature" as well as the formula "ownership obliges" reflecting the social function of ownership (Vukolova, 2009).

The third group of authors suggest amending Article 42 of the Constitution with the provision on "the right of territorial communities of people, including indigenous small-numbered peoples, to a favorable environment in places of their residence and economic activity" as well as "providing for compensation for harm caused not only to man but also to the environment" (Davaeva, 2008).

All these suggestions are interesting in their own way and deserve the most serious attention, however, in our view, they refer to local problems and do not answer the main question - what is the reason for the apparent conflict of constitutional rules, their duplication of each other, as well as the other drawbacks considered above.

It seems that in preparing the text of the Russian Constitution of 1993, its authors tried to take into consideration two trends of the Russian constitutional regulation and (partly) the foreign experience, which led to the very unusual wording of Article 72 of the Constitution on issues of joint jurisdiction. The matter of determination of jurisdictional issues of the Federation and its subjects can involve references to areas of life and (or) branches of law (legislation). Article 14 of the Constitution of the USSR of 1936

\footnotetext{
78 of the Constitution of Azerbaijan, "environmental protection is the duty of everyone"; based on Article 53 of the Constitution of Lithuania, "the state and each person are obliged to protect the environment from harmful effects"; according to Article 38 of the Constitution of the Republic of Kazakhstan, its citizens "are obliged to save nature and take care of natural wealth", etc.
} 
mentioned both areas of life and branches of legislation; Article 73 of the Constitution of the USSR of 1977 did not mention branches of legislation, but the areas of life referred to the exclusive jurisdiction of the USSR were listed in detail. The second trend was the wish of authors of the Constitution to take into account the Soviet tradition of division of the system of law into branches, having included in the Russian Constitution all legislation branches generally accepted in Russia. The tendency to include all diversities of legal life in the narrow framework of a certain number of branches of law and legislation dates back to 1938, when at the conference of legal scholars and practitioners it was proposed to divide the system of law into 10-12 branches of law delimited according to the criterion of the subject of legal regulation (Charkin, 2012). This explains the considerable number of branches of legislation in Articles 71-72 of the Russian Constitution.

The division of the system of law into branches and identification of the precise boundaries between them still takes up a lot of the time and powers of the leading Russian scientific schools, which is not observed in European countries. The development of the legislation of subjects of the Russian Federation is a practical issue of formation of boundaries between branches of law. The regional legislator, adopting almost any law on land, must consider whether a rule, for example, about lease of land plots is a rule of civil legislation (within the exclusive jurisdiction of the Russian Federation) or a rule of land legislation (within the joint jurisdiction of the Russian Federation and its subjects). This greatly impedes the development of legislation of subjects of the Russian Federation, but this issue can be settled only through rejecting separation of competence by means of listing the legislation branches or (in terms of our topic) through the assignment of civil legislation to the joint jurisdiction.

Applying the method of "mixing" areas of life and branches of the legislation is a common practice in many European constitutions. For example, according to Article 73 of the Constitution of the Federal Republic of Germany, the exclusive competence of the Federation includes particular areas of life, for example, citizenship, money circulation, telephone communication, but not the legislation on them. However, already in the field of competitive legislative competence (Article 74) we observe a combination of areas of life and branches of law. ${ }^{7}$ Nevertheless, the reference to branches of law in Article 74 is rather an exception than the rule. In our view, the mixing of two Soviet traditions (analogues of which exist also in other countries) of referring to areas of life and branches of legislation leads to a duplication of constitutional rules, and this practice should be rejected, with the focus on one thing only. We believe that indication of areas of life will be more promising.

Sustainable development, which is defined as a duty of the state (citizen) or a field of management activity in many constitutions of countries of the world, could become

7 This article mentions civil and land law in combination with the turnover of land plots, although it is obvious that this is the same defect of the legal technique as in the Russian Constitution - it is rules of civil and land law that regulate the turnover of land plots (area of life), and this duplication makes no sense. 
one of such areas of life. For example, according to Article 8 of the Constitution of Eritrea of 1997, the state shall be responsible for managing all land, water and natural resources on the basis of balanced and sustainable development in the interest of present and future generations. In compliance with Article 16 of the Constitution of the Republic of Guinea of 7 May 2010, every person has the right to a healthy and lasting environment and the duty to defend it. This trend indicates that this concept, formulated at the UN Conference on Environment and Development held in Rio de Janeiro in 1992, starts manifesting itself increasingly at the constitutional level, which should be evaluated as positive. The importance of this trend consists in the fact that the concept of sustainable development is a question of not so much preservation of the environment as development of the economic and social fields, maintenance of their functioning, ensuring a certain level of life and its quality. Based on the mentioned international documents, environmental protection is just one of the areas within which the concept of sustainable development can be implemented.

However, in Russian juridical science, there is a rather significant focus on the environmental block of the concept of sustainable development during its discussion (Vershilo, 2008) though the negative impact on the environment in Russia is small, while development of the economic and, especially, social areas causes concern. Solely attributing "environmental" content to the concept of sustainable development is not correct, despite the undisputed importance of issues in the field of environmental protection. In this regard, it seems reasonable to supplement Article 72 of the Constitution, devoted to the joint conduct of the Russian Federation and its subjects, such areas of life, as "sustainable development".

Kelsen also called for such borrowing of rules of international law at the national level. He stated that "the basic rules of various national law orders themselves are founded on the general rule of international law order. If we understand international law as the legal order with which all states (and it means - all national law orders) comply, then the basic rule of a national law order is not just an assumption of legal thinking but a positive legal rule, rule of international law applied to the law order of a particular state" (Kelsen, 1967).

\section{CONCLUSION}

In this paper we studied the rules of the Russian Constitution from the viewpoint of Hans Kelsen and his Pure Theory of Law without using any ideological or political estimates and attitudes in order to consider the constitutional rules on nature management and environmental protection as such and to express our suggestions on how to make them better and more effective. Without trying to assess all the provisions of Kelsen's theory (many of which are ambiguous, for example, attempts to reject the categories of "value" or "justice" in law), we should note that normativism has a positive role that promotes the identification of contradictions in law, and stimulates the creation of a 
coherent system of legislation. The application of Kelsen's normativism methodology in the study of the content of rules of the Russian Constitution and of other states allowed us to consider and assess their quality without deviating from the objective to analyze the rules of law and the legal technique used in their formation, issues of ideology, sociology or other causality of some or other decisions of the legislator. As a result, we came to the conclusion that the constitutional terminology in Russia has a number of significant defects in connection with which it appears necessary even now to conduct a search for options of enshrining rules on environmental protection and use of natural resources corresponding to realias of the 21 st century in the future Constitution of the Russian Federation. Having used the postulate of the normativism theory about the hierarchical pattern and consistency of legal rules that differ in the level of legal force, we identified a number of contradictions between the Russian Constitution and the rules of branch (natural resources and environmental) laws, justifying the need to either correct the provisions of such laws or to introduce amendments to the Constitution. In this sense, the potential of the normativism doctrine (not claiming to be universal and exclusive) allows effective assessment of the content and conflicts of rules of law without being distracted by minor issues. Though this approach should not be absolutized, the formal dogmatic method demonstrates high efficiency within the framework of scientific studies dedicated to resolution of local legal doctrinal problems. Let us note that within the normativism concept the basic rule is not enshrined in any legal texts (rules) - it is a "transcendental logical postulate", which states as follows: "one must behave as prescribed by the constitution" (a particular constitution of the state).

This important postulate signifies (in terms of the topic of our paper) the need to substantiate not only the problem of formation of a consistent system of environmental and natural resources legislation in every state, including Russia, but also the necessity to develop the system of guarantees of everyone's rights to a favorable environment, land rights of citizens and legal entities, as well as to specify the system of environmental and natural resources duties. Such a postulate of normativism as an assessment of the effectiveness of constitutional rules is also rather promising for scientific studies on constitutional regulation of social relations. Use of this methodology showed ineffective, unapplied rules of the Russian Constitution, dedicated to both environmental duties and issues of constitutional regulation of types and forms of ownership of natural resources. This leads to our conclusion about the need to correct the text of the Constitution, which is inevitable for every country of the world, since even in the Constitution of the USA, which is a model for many countries of the world, twenty-seven amendments have been made over the past 200 years (Kaplunov, 2015). This need is especially distinct in countries with transitional political regimes, such as most countries of the post-Soviet space, including Russia. It appears that in the course of enhancing the constitutions of Russia and other republics of the former USSR it is necessary to take into account the drawbacks of the legal technique of the current Russian Constitution and not to repeat them. 


\section{REFERENCES}

Basik, V. P. (2003). Duties of citizens of the Russian Federation and foreigners. Moscow: Moscow University Press.

Boyko, A. I. (2004). Naturalness of legal duties and incorrectness of exaggeration of legal rights. Legal policy and legal life, 1: 56-60.

Brinchuk, M. M. (1998). Environmental law (law of the environment). Textbook for institutions of higher legal education. Moscow: Jurist.

Brinchuk, M. M. (2011). Environmental law. Moscow: MPSI, MODEK.

Charkin, S. A. (2012). Land legal relations as an interbranch legal category. Moscow: Publishing House Yurait.

Chernushenko, S. S. (1999). Legal regime of specially protected natural areas. Candidate thesis. Saratov State Academy of Law.

Chertova, N. A. (2007). Constitutional legal fundamentals of ensuring environmental security of the Russian Federation (in terms of experience of the northern regions). Doctoral thesis. Russian Academy of public service under the President of the Russian Federation.

Chubukov, G. V. (2003). Natural resources law of the Russian Federation. Moscow: MGIU.

Constitutional Court of the Russian Federation (2004). Decisions of the Court. Judgment of 23 April 2004 No. 8. URL: http://www.ksrf.ru/en/Decision/Judgments/ Documents/2004\%20April\%2023\%208- P.pdf (30.07.2018).

Constitutional Court of the Russian Federation (2008). Ruling of the Constitutional Court of the Russian Federation of 17 June 2008 "On Refusal of Acceptance for Consideration of the Complaint of the Citizen Konstantin Mikhailovich Foris of Violation of his Constitutional Rights by Paragraph 10, Subitem 2, Item 1, Article 49 of the Land Code of the Russian Federation. URL; http://www.consultant. $\mathrm{ru} /$ cons/cgi/online.cgi? req=doc\&base=ARB\&n=76233\#032964 55765113768 (30.07.2018).

Davaeva, K. K. (2008). Constitutional right to a favorable environment in the Russian Federation: legal regulation and judicial protection. Candidate thesis. Russian Academy of Justice.

Davydova, M. L. (2010). Theoretical and methodological issues of the concept and content of the legal technique. Doctoral thesis. Volgograd State University.

Demyanenko, V. V. (2004). Farm production cooperation in modern Russia: legal issues of formation and development. Doctoral thesis, Saratov State Academy of Law.

Dzagoev, S. V. (2008). Civil legal regulation of acquisition of rights to land plots which are in public ownership. Candidate thesis, Kuban State Agrarian University.

Epshtein, S. (2006). Constitutional legal delineation of authorities in the field of land relations in the Russian Federation. Candidate thesis. Russian Academy of Public Administration under the President of the Russian Federation.

Erofeev, B. V. (1996). Environmental law of Russia. Moscow: Jurist. 
Faizullin, G. G. (2010). Food security of Russia in the context of national security. Law and state: theory and practice, 9: 98-104.

Fokin, A. V. (2006). Environmental rights and duties of man and citizen (theoretical legal aspect). Candidate thesis. Volgograd Academy of the Ministry of Internal Affairs of the Russian Federation.

Gafurov, A. R. (2010). Essence of the category "energy security" and its place in the general structure of security. Bulletin of Murmansk State Technical University, 13(1): 178- 182.

Ivanov, A. A. (2016). Reflection of issues of preservation of biological diversity in the Russian nature protection legislation. Tolyatti: Kassandra.

Kaplunov, A. S. (2015). Constitutional legal significance and role of amendments to the Constitution of the USA of 1787. Young Scientist, 19: 488-491.

Kasprova, Y. A. (2014). Environmentally unfavorable areas: peculiarities of the legal regime. Candidate thesis. Institute of State and Law of the Russian Academy of Sciences.

Kazantsev, N. D. (1965). Scientific fundamentals of differentiation and integration of the legislation regulating use and protection of natural resources. Bulletin of Moscow State Law University, 2: 5-6.

Kelsen, H. (1967). Pure Theory of Law. Berkeley: University of California Press.

Kelsen, H. (1987). Pure Theory of Law. Moscow: Academy of Sciences of the USSR.

Khalilova, T. V., Leontieva, L. S., and Gainullina, L. F. (2016). Corruptness of relations in the field of nature management, or "curse of natural resources". Current issues of economy and law, 1: 26-34.

Kleandrov, M. I. (2008). Ownership right of state corporations: some issues. In: Tuzov, D. O. (ed.), Real rights: system, content, acquisition: collection of research papers in tribute to Professor B. L. Khaskelberg (pp. 30-38). Moscow: Statute.

Kleshchenko, A. (2013). Shooting attack of the Russian White House in 1993. Chronicle of events. Argumenty i Fakty (AiF.ru). URL: http://www.aif.ru/dontknows/file/ rasstrel_belogo_doma_v_1993_godu_hronika_sobyti y (30.07.2018).

Kolbasov, O. S. (1976). Ecology: politics-law. Moscow: Nauka.

Kozhevnikov, K. K. (2015). Environmental legal essence of nuclear security. Current issues of Russian law, 4: 73-77.

Kraevsky, A. A. (2014). Pure Theory of Law of Hans Kelsen and modern legal positivism. Candidate thesis. Institute of State and Law of the Russian Academy of Sciences.

Kuzmin, A. G. (2007). Legal entities as subjects of constitutional legal relations: Candidate thesis. Chelyabinsk State University.

Mayasov, D. Y. (2013). Constitutional fundamentals of territories with a special status in the Russian Federation. Candidate thesis. Institute of State and Law of the Russian Academy of Sciences.

Melikhov, A. I. (2007). Private ownership right to land plots: constitutional legal aspect. Candidate thesis. Volgograd Academy of the Ministry of Internal Affairs of the Russian Federation. 
Mukhitdinov, N. B. (2010). Legal issues of subsoil use. In: Alukhanov, E. O., Seitzhanov, A. A., Mukhitdinov, A. N., Mukhitdinov, N. N. and Mukhitdinov, E. N. (eds.), Selected works in 9 volumes. Volume 1 (pp. 22-250). Almaty: Nurai Print Service.

Petukhova, E. P. (2015). Constitutional legal regime of natural resources. Candidate thesis. Higher School of Economics.

Proshina, K. Y. (2014). Constitutional legal duty in the field of natural resources relations: issues of theory and practice. Theoretical \& Applied Science, 2(10): 173-177.

Reimers, N. F. (1990). Nature management: reference dictionary. Moscow: Mysl' publishing.

Samusenko, L. A. (2015). Joint ownership of land plot: issues of legal enshrining. Vesnik of Yanka Kupala State University of Grodno, 4(3): 63-66.

Selifonova, S. Y. (2012). Legal regulation of land relations with participation of foreign persons. Candidate thesis. Institute of State and Law of the Russian Academy of Sciences.

Serikov, O. T. (2010). Constitutional fundamentals of environmental protection in the Republic of Kazakhstan: issues of theory and practice. Doctoral thesis. Kunaev University.

Soldatenkov, O. O. (2009). Constitutional fundamentals of the public ownership right to natural resources. Candidate thesis. Omsk State University.

Sotnikova, M. S. (2009). Municipal ownership right to land plots in the Russian Federation. Candidate thesis. Kuban State Agrarian University.

Takhvatulina, N. K. (2006). Ecologization of legal regulation (theoretical legal research). Candidate thesis. Volgograd Academy of the Ministry of Internal Affairs of the Russian Federation.

Tarkhov, V. A., Rybakov, V. A., and Fateev, M. A. (2006). Collective (corporate) form of ownership. Jurist, 12: 27-29.

Vakula, M. A. (2011). Constitutional legal regulation of environmental protection and rational nature management in subjects of the Russian Federation (in terms of the city of Moscow). Candidate thesis. Peoples' Friendship University of Russia.

Velento, I. I. (2003). Issues of macrolegal regulation of ownership relations in the Republic of Belarus and the Russian Federation. Grodno: Grodno State University.

Velieva, D. S. (2011). Constitutional legal fundamentals of environmental security in the Russian Federation. Doctoral thesis. Saratov State University named after N. G. Chernyshevsky.

Vershilo, N. D. (2008). Environmental legal fundamentals of sustainable development. Doctoral thesis. Institute of State and Law of the Russian Academy of Sciences.

Vorotilin, E. A. and Machin. I. F. (eds.). (1996). History of political and legal studies: Anthology. Moscow: College of Law of Moscow State University.

Vukolova T. V. (2009). Constitutional legal fundamentals of environmental protection in Russia and Germany. Candidate thesis. Institute of State and Law of the Russian Academy of Sciences. 
Vystorobets, E. A. (2012). Environmental provisions of constitutions: collection. Moscow: Ufa: MIRmpOS.

Zhelezinsky, A. A. (2011). Constitutional fundamentals of environmental protection in the Russian Federation. Candidate thesis. Saratov State University named after N.G. Chernyshevsky. 


\title{
USTAVNOPRAVNA REGULACIJA ZAŠTITE OKOLIŠA I UPRAVLJANJA PRIRODOM U POSTSOVJETSKOM PROSTORU: PITANJE PRAVNE TEHNIKE
}

Aleksey Anisimov i Anatoliy Ryzhenkov

\begin{abstract}
Sažetak
Rad analizira pojmovlje i sadržaj Ustava Ruske Federacije te ustava nekoliko republika bivšeg SSSR-a kojima se regulira područje upravljanja prirodom i zaštitom okoliša, oslanjajući se na perspektivu normativističke metodologije Hansa Kelsena, posebice cistu teoriju prava. Autori argumentiraju da ustavna pravila zemalja postsovjetskog prostora imaju niz nedostataka poput ponavljanja ili neadekvatne refleksije pravne stvarnosti. Na temelju toga zaključuju da je potrebno pronaći načine na koje bi se u ruskom Ustavu oblikovala pravila o zaśtiti okoliša i korištenju prirodnih resursa a koja bi odgovarala realiji 21. stoljeća. To bi omogućilo stvaranje adekvatnog sustava koji bi svima garantirao pravo na zdrav okoliš, te koji bi gradanima i pravnim osobama osigurao pravo na prirodne resurse, ali i propisao njihove obveze prema okolišu i prirodnim resursima.
\end{abstract}

Ključne riječi: ustav, prirodni objekti, prirodni resursi, prirodna bogatstva, pravna pitanja, pravno pojmovlje

\section{VERFASSUNGSRECHTLICHE REGULIERUNG DES UMWELTSCHUTZES UND DER NATURVERWALTUNG IM POSTSOWJETISCHEN RAUM: EINE FRAGE DER RECHTSTECHNIK}

\author{
Aleksey Anisimov und Anatoliy Ryzhenkov
}

\begin{abstract}
Zusammenfassung
Die Arbeit analysiert die Termini und den Inhalt der Verfassung der Russischen Föderation sowie die Verfassungen einiger Republiken der ehemaligen GUS, die den Bereich der Naturverwaltung und des Umweltschutzes regeln, in Anlehnung an die Perspektive der normativistischen Methodologie von Hans Kelsen, insbesondere an die reine Rechtstheorie. Die Autoren argumentieren, dass die Verfassungsregeln der Länder im postsowjetischen Raum eine Reihe von Mängeln aufweisen, wie z. B. Wiederholungen und / oder eine inadäquate Widerspiegelung der Rechtswirklichkeit. Auf Grund dessen schließen sie, dass es nötig ist, Art und Weisen zu finden, wie in der russischen Verfassung die Regeln zum Umweltschutz und zur Nutzung von Naturressourcen formuliert werden sollten, die der Realität des 21. Jahrhunderts gerecht wären. Das würde die Schaffung eines adäquaten Systems ermöglichen, das allen ein Recht auf eine gesunde Umwelt gewähren würde, das Bürgern und Rechtspersonen ein Recht auf Naturressourcen sichern, aber zugleich ihre Pflichten der Umwelt und den Naturressourcen gegenüber vorschreiben würde.
\end{abstract}

Schlüsselwörter: Verfassung, Naturobjekte, Naturressourcen, Naturreichtümer, rechtliche Fragen, rechtliche Terminologie 